\title{
Esitor's Messase
}

$\mathrm{W}$

ith the heartening news of India being the world's leading economy by 2050 , we are also faced with the gloom of simultaneous erosion of human values. We are bombarded daily with screaming headlines of scams in one form or the other, only pointers of declining personal standards and principles. In the literary context too, several journals of scientific nature are on the rise and with the need to score on points and credentials, there is a clamour to fulfill that need at any cost and even going to the extent of plagiarism. Writing of scientific content takes hardwork, research and loads of time and effort on the part of the authors. And there have been instances similar to a form 'literary-piracy' of reusing that content. The solution to this menace of course, are in built by systems, but require also self restraint and regulation on our part to be honest and truthful in making sure our work is original.

We at the JCD desk strive towards this goal and earnestly urge contributors to stick to these principles as we are now open to content from outside which makes it even more mandatory to pass on this message to all, within and outside of college.

A journal should be a common ground for sharing and disseminating scientific content for the benefit of the dental and medical community. And we strive to maintain that quality of work that goes within its pages. We therefore urge and call upon both staff and students to undertake work of high standards, innovation and quality that can benefit all.

MGM will soon be launching our own website wherein these Journals will be available online and can be easily downloaded. We do not intend to lock in the content but wish that the journals are freely available to all, can be accessed and used for enhancing self learning. We however hope as from my earlier plea that these may not be misused or reproduced illegally.

With this I once again thank all those who have put together this 3rd issue successfully, both contributors and committee members and hope you enjoy its content.

Dr. Jyotsna Galinde

Assoc. Dean, Post Graduate Studies Prof \& Head, Dept. Oral \& Maxillofacial Surgery, MGM

\section{ANNOUNCEMENT}

In keeping with our endeavour to disseminate scientific knowledge beyond the boundaries of our institution, the Journal now invites Scientific articles from other institutions. We are happy with the response received so far and we look forward to an even bigger response in future. All contributing authors are requested to follow the author guidelines outlined and send in your articles at the specified address. 